\title{
Pathology of Land Transfer and its Effects on the Destruction of Natural Resources and Land Speculation Phenomenon in Iran
}

\author{
Habibollah Mahdavivafa \\ Agricultural Research and Instruction and Natural Resources Center of Tehran Province, \\ Agricultural Research, Education and Extension Organization (AREEO) \\ Email: hmahdavi2000@gmail.com \\ Rahman Sharifi \\ Agricultural Research and Instruction and Natural Resources Center of Tehran Province, \\ Agricultural Research, Education and Extension Organization (AREEO) \\ Email: R_sharifi46@gmail.com
}

\begin{abstract}
The natural resources' lands are enumerated amongst the most important sources of the country's wealth. Moreover, the pastures and forests not only play a determinant role in creating jobs and developing the industries and factories related to them, but also they are envisioned as the sources supplying the people with their foodstuff. Corresponding to the law on the conservation and exploitation of the forests and pastures, any abuse to the areas of the forests, pastures and thickets within the format of residential constructions and others is forbidden and would be case-specifically included by the regulations related to the law on the prevention of forcible occupation. The discussions on policy-making system related to development planning are infeasible without taking the legal issues of the natural resources and environment into account and knowing the reality that the natural resources are limited in our country and the renewal trend is very slow and revival is occasionally impossible due to the extents of the destruction, the collection of the interventions by the various executive organs in the development process should be accordingly in proportion to the status of the resources and in adherence to prospective considerations and country's sustainability. Having a short glance at the regulations related to the natural resources, the current research dealt with the destruction of the natural resources and land speculations in Iran following the transferring of the lands.
\end{abstract}

Keywords: Natural resources, Land ownership, Land speculation, Legal system

\section{Introduction}

In Iran, forests, pastures, water, soil and species' diversity account for renewable natural resources. In between, forests and pastures are of a far greater importance due to their vastness and value and protection and revitalization of these important resources is considered as the duty of every individual member of the society. In Act 45, the constitution stipulates that forests, pastures (including the wooded and non-wooded ones), natural thickets, seas, rivers and mountains are public properties with the government being the owner of them. Furthermore, Act 50 of the constitution emphasizes on the idea that the conservation of the environment is the public duty and underlines the prohibition of the devastative activities. A historical glance at the collection of the civil reconstruction measures and plans in line with the country's development shows that although the necessity of conserving the natural resources and revitalization and development of them has been emphasized in nearly all the programs, most of the experts and officials of the country's natural resources believe that the intensity of the destruction of these resources has been incremental and it is far from being under control. In fact, factors like the daily increase in the population, disproportionate change in the forest and pasture lands' uses for supplying the country's development needs, lack of coordination between the executive organs, elimination of the people's management following the nationalization of the forests and pastures and leaving it unsubstituted with a proper management, negligence of the expertise and competency in the management positions of the organs proctoring the natural resources and so forth have been and are amongst the cases exerting a large deal of effect in the intensification of the destruction of these resources but the ambiguity and shortfall in the existent regulations and rules and weakness of the judicial authorities' support of the enforcement of these regulations have had a lot more notable effects hence these should be taken into consideration. Although there are various rules and regulations enacted in Iran's legal system regarding the ownership of lands and conservation of natural resources, protection of the proprietary rights and prevention of land uses' change and illegal occupation of lands, the confrontation with such measures is practically faced with numerous legal, social and economic problems. 
The researches worldwide demonstrated that the legislature and the courts play important roles in constructing modern ownership laws in national level. However, many of the properties of the modern legal system emerging in such judicial domains as France, Germany, Italy, England, US or Canada are different. The ownership law is comprised of regulations under special subjects that may be matching in various jurisdictions. As an example, land registration is not identical in France and England [1].

- Ahmad Shams (1996) ,In a research called "the investigation of the legal system of nationalized lands”, has dealt with the legal nature of such a measure as nationalization of the lands and its position in the regulations as well as the outcomes of lands' nationalization and analyzed the lawsuits related to this type of lands [2].

- General law research group (2008 ),under the title of "legal system of land ownership in the other countries and its relationship with land speculation", the general law research group pointed out that the comparative investigations around the globe show that the land speculation is a crime essentially interlaced with land proprietorship system and that such measures as increasing the government's responsibility in proper exploitation of the land in adherence to the public interests, exact specification of the registered maps and perfect implementation of the cadaster system and adoption of intensive rules and regulations against land occupiers can be taken for fighting the occupation of the general lands. In Iran, land speculation is caused by numerous legal, economic, urban, cultural and social factors [3].

- Mahdi Karimi (2003) ,In another research titled "penal support of the natural resources in Iran’s laws", Mahdi Karimi (2003) dealt with the punitive rules and regulations in Iran about the legal and judicial issues of the natural resources for recognizing the penal supports. It can be seminally made clear following the recognition of the enacted rules and regulations that what measures have been so far taken by the legislator regarding the support of the natural resources and secondly these rules and regulations can be precisely investigated so as to figure out the strong points and the possibly weak points [4].

- Abu Al-Hasan Mojtahed Solaymani (2013) explained the process of recognizing the national lands' exceptions and objections to the courts' sentences in a research called "recognizing national lands from the legal exceptions and objections to them".

- Mahdi Teymuri (2016), In a study entitled "investigating the legal status of the nationalized lands and individuals' ownership exceptions and method of objecting to them”,) pointed out that although all of the country's natural areas were placed under the government's ownership in 1962, the stabilization and establishment of the government's ownership and invalidation of the individuals' documents entails certain formalities that have been subsequently expressed. The recognition operation has been commenced in adherence to the enacted regulations since the approval of the forests' nationalization law and it is still in progress. In the last enactment, the legislator has obliged the government to take measures parallel to the stabilization of the government's ownership and exertion of efficient management and proper conservation and exploitation of the nationalized resources through accomplishing auditing operations and acquiring ownership deeds for nationalized areas to the name of the government [6].

\section{Materials and Methods}

The present study has been carried out based on library and documentary research. This study employed a descriptive-analytical method based on the regulations governing land transfer in the country and performance of the responsible organs.

According to the Act 45 of the constitution and corresponding also to the Article 1 of the country's forests nationalization law, the land and superstructure of all the forests and pastures and natural thickets and forest lands of the country were considered as public properties and belonging to the government. The article 2 of the aforesaid law, as well, has placed the conservation, revitalization and development of the abovementioned resources and their exploitations on the shoulder of the forestry organization. Article 56 of the law on the conservation and exploitation of the forests and meadows and article 2 of the law on the conservation and support of the country's forest resources and reservoirs, as well, stipulated that the forests and pastures' organization were responsible for the recognition of the natural resources and exceptions mentioned in article 2 of the law on nationalization of the forests and pastures in adherence to the definitions presented in the law on the conservation and exploitation of the forests and pastures [7]. It was for the first time in the appended article 268 that the general penal law criminalized the discussed behavior on $5^{\text {th }}$ of December, 1959. The appended Article 268 of the general penal law stipulated that "should anyone set the ground for occupying the others' properties via taking preparatory measures like digging foundations and so forth or file a forcible occupation lawsuit against the real owners for preventing their ownership ... s/he will be sentenced to correctional imprisonment”. The turning point in the social and legal evolution trend of the national lands was the enactment of the law on the nationalization of the forests and pastures in 1962 at which time the announcement of the 
nationalization of the lands qualified for the legal conditions and their ownership by the individual society members and general public caused the emergence of such a subject as forcible occupation of the national lands in the society. Since this time, regarding the lands of the pastures, areas of the natural resources and wasted or abandoned or unpossessed lands were considered national and owned by the general public, individuals became inclined towards various methods of forcible occupation of the national lands with the motivation of taking possession of the national lands [11].

After that, article 55 of the law on the conservation and exploitation of the forests and pastures, passed in 1967 and amended on $9^{\text {th }}$ of April, 1969, criminalized the foresaid behavior. This law stipulated that "anyone abusing the national resources mentioned in the article 1 of the law on nationalization of the country's forests with occupation intentions, would be sentenced to correctional incarceration from one to three years”. After the Islamic Revolution of Iran, article 134 of Ta'azirt Laws, passed in 1983, was replaced for the aforementioned articles. In the end and in 1996, it was with the enactment of the Islamic Penal Code of Law that its article 690 was approved as the last legislation step for criminalizing the foresaid behavior. This way and following the obliteration of the appended article 268 of the general penal law, article 55 of the law on the conservation of the forests and pastures and article 134 of Ta'azirt Law, now it is only article 690 of the Islamic Penal Code of Law that is used as a basis [8].

\section{Defining the Natural Resources in the Law:}

According to the Islamic Consultative Assembly's enactment on $2^{\text {nd }}$ of April, 2012, natural resources include all the lands and superstructures of the forests, pastures, natural thickets, forest lands, grasslands, bushlands, canebrakes, wetlands, lagoons, newly developed lands, coastal lands, wastelands, specific lands, governmental lands, wilderness and mountainous lands, deserts, dune lands, soil resources, water channels, sea beds, lakes, bays, islands, hand-planted forests, watershed parks, forest parks, nursery stocks and stations of seed and seedling production and general genetic reservoirs, natural ecologies and their components, forests and pastures created in the course of the organizations' performing of their duties for revitalizing, amending and transforming the resources as well as the other similar sources created or to be created by the ministry of agricultural jihad and its subordinate organizations and units.

\section{Discussion}

\section{Legal System of Land Ownership in Iran:}

Before the Islamic Revolution, the country's lands were divided into three sets of governmental lands, lands belonging to the royal family and private (masters') lands; after the Islamic revolution, it was with the confiscation of the royal family's properties in favor of the Islamic Republic of Iran that the currently land ownership in Iran was divided into two sets of lands belonging to the government (private or public individuals) and lands belonging to the private individuals [3].

The law on the nationalization of the country's forests was passed on $17^{\text {th }}$ of January, 1963. Article 1 and its note are amongst the most significant articles by the force of which the lands and superstructures of all the forests and pastures and natural thickets and forest lands of the country are considered as parts of the public properties hence belonging to the government since the approval of this legal enactment even if individuals are found having occupied them before this date and having received ownership deed. Preservation, revitalization and development of the aforesaid resources and exploitation of them are the duty of Iran's forestry organization.

In this regard, the root of land speculation phenomenon can be sought in the first note to this article. Based on this note, the forestry organization is allowed to shoulder the exploitation of the abovementioned resources in person and/or delegate it to the other individuals via concluding the required contracts. As for the primary ownership of the lands, as well, it can be stated according to the existent rules and regulations that the ownership of the urban lands and wastelands is originally belonging to the government except the cases transferred to the private persons in the course of conveyances. Corresponding to article 3 of the law on the newly created and coastal lands, passed on $20^{\text {th }}$ of July, 1975, "all of the country's newly created lands belong to the government and individuals do not have the right to demand their registration under their own names and any request made for the aforesaid lands will be invalidated and the local landed property registration offices are obliged to accept the registration requests for the aforementioned lands only after confirmation by the ministry of agriculture and natural resources and/or other governmental organizations that own parts of these lands following the verifications by the ministry of agriculture and natural resources” [11].

\section{Land Ownership Legal System and Land Speculation Phenomenon:}

Although there are various rules and regulations enacted regarding land ownership, protection of proprietary rights and prevention of land uses' change and illegal land occupation in Iran's legal system, the confrontation with such a phenomenon as land speculation in the country is practically faced with numerous legal, social and economic problems. Essentially, one of the substantial problems in this area is the absence of a clear-cut definition of this antisocial phenomenon and the multidimensional nature of its factors. There is no such a criminal title as land speculation in Iran's statutory provisions and this expression has become more prevalent in 
the administrative and social customs. However, the examples of such a crime can be expressed as follows: fabrication of documents, occupation of the lands in the bed and banks of the rivers and natural resources, change in the uses of agricultural lands and gardens and their transformation into the barren lands and finally requiring of the legal authorities to the prescription of changes in the use of the external urban lands and internal lands within the service domain of the cities via winning the satisfaction of the municipalities and the commission subject of article 5 of the law by the supreme urban engineering council for selling them for higher prices. Therefore, at least two material elements of illegal changing of the land use and illegal occupation of the land exist in every land speculation action and they may be performed concomitantly or in separate [3]. Iran's penal rules and regulations have not directly criminalized land speculation but the required legal grounds have been set for fighting this action under numerous criminal titles like illegal change in the land use and illegal occupation of the public lands [11]. Amongst some of the most important of these regulations that are more related to the natural resources, the followings can be pointed out:

- Illegal occupation of the national and governmental lands (article 690 of the Islamic Penal Code of Law): Any legal or real persons that have to set the ground and take preparatory measures through excavating foundations, laying walls, changing the distances, destruction of the borders, burrowing, stretching ditches, digging well, planting trees and farming and others of the like in the agricultural lands, including cultivated or in fallow, forests and nationalized pastures, mountains, gardens, nursery stocks, water resources, springs of water, natural ditches and national parks, agricultural, ranching and domestic animal raising installations, lands for industrial farming, wastelands and barren lands and other lands and properties belonging to the government or its affiliated companies or municipalities or endowment organization as well as the lands and properties and endowments and dedicated movable and immovable properties that have been dedicated to public interests' applications in line with occupying these lands or introducing themselves or others as rightful in doing so or performing operations without any permission from the environment conservation organization or the other qualified authorities that cause the destruction of the environment and natural resources or any intervention through any form of abuse and forcible occupation or creation of interference or prevention of the rights in the aforesaid cases will be sentenced to incarceration from one month to one year. The court is obliged to case-specifically restore the forcible occupations or interferences or prevention of rights to their former states".

- Abuse to the forests (article 55 of the law on the conservation and exploitation of the forests and pastures passed on $16^{\text {th }}$ of August, 1967): "Any abuse to the forests, pastures, thickets and nationalized forest lands is forbidden and it will be case-specifically included by the regulations of the law on the prevention of forcible occupation" [3].

- Changing the land use (article 1 of the law on the preservation of the agricultural lands and gardens' uses): "In order to preserve the agricultural lands and gardens' uses and keep them striving and productive, the change in the uses of the agricultural lands and gardens' uses outside the legal limits of the cities and estates is forbidden except in necessary cases since the enactment of this law" [12].

- It is evident considering the high profitability of housing and land sector and the high motivation of the opportunists in this sector for acquiring early and illicit profits that the abominable phenomenon of land speculation would be entangling many of the unprotected areas of the natural resources as a vivid challenge and threat, especially in the regions with favorable climates as well as in the vicinity of the cities and industrial regions in which the lands are valuable and the prices are higher.

\section{Land Transfer and its Effects on the Destruction of the Natural Resources:}

Amongst the most important issues in conflict with the principle of protecting the natural resources, and leading to their destruction in a vast level, is the subject of "transferring the lands of the natural resources" and their transformation to be used for various purposes. A short glance at the undertaken land transfers most of which have been carried out based on the regulations, shows that the technical and bioenvironmental criteria and scales based on land management and optimal land use have not been and are not being taken into consideration after nationalization of the country's forests and pastures. On the other hand, besides legal transferring and changing the uses of the lands in the natural resources, the illegal occupation and abuse to these areas have added to the intensity of destruction. In between, the role of the various regulations in transferring the lands and setting the ground for occupying and destroying the forest and pastures' lands as well as untimely implementation of the regulations are of great importance. During the past 30 years, at least 760 thousand hectares of the natural resources' lands have been abused and occupied. Reports offered by the country's organization of forests and pastures demonstrate that some 69 thousand hectares of the foresaid amount has been in the forest areas and the remaining 698 thousand hectares have been mostly from the country's pastures [13]. 
- Approval of a single article to the law on the determination of the status of the disputed land subjects of enforcing article 56 of the law on conservation and exploitation of the forests and pastures, passed on $19^{\text {th }}$ of May, 1988, by Islamic Consultative Assembly resulted in declaring uncanonical of the sentences issued by the commission subjects of article (56) until before 1988 and the individuals with interests therein were allowed to object to the final sentences regarding the nationalized lands. The enactment of this law practically caused over 500 thousand hectares of the lands that had been previously recognized as national resources to be considered as exceptions following which the government was deprived of their ownership. The report offered by the forests, pastures and watershed management organization showed that objections have been made for 13 million hectares of the lands during the years from 1993 to 2003 in the course of the enforcement of the aforesaid single article; during this period, 60 thousand sentences have been made, the result of which, has been the reduction in the national lands for 345 thousand hectares and their addition to the area of the country's exceptional lands.

- In enforcing the legal bill for amending the law on the method of transferring and revitalizing the lands in the government of Islamic Republic of Iran, passed in 1980 by the Revolution Council, over 1300 thousand hectares of the national and governmental lands have been transferred to real and legal persons till the end of 2003 with $40 \%$ having been for the implementation of agricultural plans and the rest being dedicated in the course of enforcing article 32 of the procedures of the aforementioned law's bill for executing the nonagricultural plans. In addition, over 840 thousand hectares of the natural resources' lands have been transferred to the real and legal persons in the course of enforcing the other legal articles such as article 75 of the law on receiving of some of the government's incomes, article 34 of the law on the conservation and exploitation of the country's forests and pastures and article 29 of the procedures and criteria and conditions of transferring the national and governmental lands. It is observed that another 2180 thousand hectares of the lands in the natural resources`areas have been transferred and changed in their uses in addition to the amounts of the transformed lands mentioned in paragraph (1).

- The law on the amendment of article (34) of the law on the conservation and exploitation of the country's forests and pastures, as well, is amongst the other cases enacted with the goal of reducing the open and unjudged files regarding the occupied lands in the judicial authorities in 1994. Besides issuing the legal permission for the transferring of the national lands under the title of occupation, this law not only did not succeed in reducing the destructions, but also made many other individuals who were witnessing the occupation of the natural resources' lands and the trends of legal transferring of the lands to their abusers, think about the occupation of the lands as a result of which part of the natural resources' areas that had been remained immune of the abuse, was subjected to destruction. On the other hand, some of the abusers are still keeping on their forcible occupation of the lands in the hope of the extension of the term and amendment of the law.

\section{Pathology of Policy-Making in Natural Resources`Legal System:}

During 1979 and 1980, the enactment of the law on the transferring and revitalization of the lands belonging to the government of Islamic Republic of Iran and approval of the legal bill for amending the law on the method of transferring and revitalizing the lands in the government of Islamic Republic of Iran and its later amendments, left a considerable deal of effect in the use of lands and facilitation of transferring the areas of natural resources and, besides providing a new definition of the types of the lands and areas, the method of their transferring and segmentation was determined without paying serious attention to the policies of proper exploitation of the lands and specification of the optimal uses of them. In 1992, Islamic Consultative Assembly enhanced the grounds for the protection of forest varieties and species via approving the law on "the conservation and support of the natural resources and the country's forest reservoirs". In 1994, Islamic Consultative Assembly enacted the law on "the reception of part of the government's incomes and use of it in the specified cases" and allowed the selling and final conveyance of the nationalized and/or governmental land subjects of articles 31 and 32 of the procedures of the legal bill for amending the law on the transferring and revitalization of the lands in the government of Islamic Republic of Iran, passed on $21^{\text {st }}$ of May, 1980, by the Islamic Revolution Council.

On $29^{\text {th }}$ of October, 1994, the Country's Exigency Council revised the article 34 of the law on the conservation and exploitation of the forests and pastures of the country and obliged the ministry of agricultural jihad to transfer or sell all the country's plateau forest lands in the north and the unwooded national pastures within three years the use cases of which had been changed until the end of 1986 without legal permission in exchange for rentals or specified prices. The enactment of this law practically caused all the illegal occupations and abuses to gain legal visage and it was indeed a seal confirming the occupations and destructions and this issue paved the way for new occupations of the natural resources' lands with the motivations of land possession. On the other hand, due to the vastness of the subject and filing of a large number of lawsuits in the executive branch and considering the fact that the enforcement of this law within three years was infeasible, the aforesaid amendment 
law was extended in its term in 2000 for another three years and ministry of reconstruction jihad (agricultural jihad) was obliged to take measures until the end of 2003 for determining the statuses of the lawsuits filed till 2001. Ministry of agricultural jihad (the country's forests, pastures and watershed management organization) could not finish the assigned task until the end of 2003 despite the emphasis made in the law thereon due to the volume and vastness of the subject and the enforcement of this law was extended to the end of the current year eventually following the suggestion and enactment of a paragraph of the note 20 to the law of 2004's overall country's budget. Besides the abovementioned cases, article 108 of the third five-year development program is consisted of two paragraphs with its paragraph (A) permitting the transferring of the national lands in macroeconomic level for making use of the specialized entrepreneur forces in the water and agriculture sector and paragraph (B) permitting the transferring of the national lands to the nomads and common exploiters and ranchers for freeing the natural resources' areas and exerting correct management on them. It can be clearly understood in an investigation of the existing natural resources' regulation that the most important and most influential of them was the law on the "conservation and exploitation of the forests and pastures" that was enacted in 1967 and some cases of it were modified during the later years.

In fact, the seventh chapter of the law on the conservation and exploitation of the country's forests and pastures pertains to the various regulations, amongst the other cases, on the duty of the courts and prosecuting offices before this law, recognition of the national from exceptional resources, responsibilities of the forest guards, punishment for the occupation of the forests and so forth. Amongst the most difficult legal cases in the enforcement of the law [13] on the nationalization of the country's forests, is the article (56) of the law on the conservation and exploitation of the country's forests and pastures with its outcomes and effects still lingering on to the present time and it is predicted in case of the continuation of this law's effect and according to the value of the land and the profits obtained thereof that the resultant problems will be a heavy burden on the shoulder of the executive organ proctoring the country's natural resources. This article held the then ministry of natural resources responsible for the recognition of the nationalized resources and exceptions and provided the objectors to the decisions made by the ministry of the natural resources and/or forests and pastures`organization with a maximum one-month respite following the announcement by the aforesaid executive organs. Based on this article, objections by the interested individuals were investigated in a commission comprised of governor, court head and person in charge of the county's natural resources and the decision made by the majority of the members of the commission that has been established at most within three months after the reception of the objection has been recognized definite and indispensable. In 1975, the aforesaid legal article was corrected with the appending of two notes but the definiteness of the commission's decision has been still underlined. On $19^{\text {th }}$ of May, 1988, Islamic Consultative Assembly enacted a single article to be added to the law on "determination of the status of the disputed land subjects of the enforcement of article 56 of the law on the conservation and exploitation of the forests and pastures" and increased the number of the aforementioned commission's members from three to seven individuals and stipulated that after the announcement of the expert decision by the seven-person delegation, the judge's sentence will be indispensable except for the three canonical cases mentioned in articles 284 and amended article 284 of the criminal trial procedures. In fact, the enactment of this law and its procedures caused the prolongation of the recognition and mandatory decisiveness of the national resources' lands and the interested parties gained the the right to object to the issued sentences even after the ownership deeds were issued to the name of the government. The result of such an action is the absence of a specified demarcation between the national lands and legal exceptions for the people for a long period of time and this would be followed by the setting of the grounds for the occupation of the lands and profiteering of the land speculators. In addition to the reasons stated in paragraphs (A) to (D), there are other cases like the lack of transparency, contradiction and juxtaposition of some of the existent regulations related to the activity area of the other executive organs, legal requirement for the enforcement of the existent regulations, correction of the supervisory system and formations and enhancement of the regulations related to the natural resources for attaining sustainable development that underline the necessity of synchronizing, correcting and completing the law on the conservation and exploitation of the country's forests and pastures [13].

In spite of the importance and prevalence of land speculation in the country, few studies and researchers have been carried about the reasons and methods of confronting this problem in the executive organs and practical and field centers, two of the most important of which have been pointed out below:

Act 90 Commission in Islamic Consultative Assembly remarked in a report on $29^{\text {th }}$ of April, 2008, regarding the status of the economic depravities and corruptions in the country that land speculation in the form of illegal transferring of the lands and illegal changes of the land uses are atop of the aforementioned depravities. The government has been asked in this report to create proper mechanisms for putting a stop on the processes of this dangerous crime considering the vast cases of land speculation in the country and take urgent measures. In 2008, as well, the legal vice chancellorship and judicial development affiliated with the judicature dealt in a comprehensive program with the investigation of the reasons of land speculation, barriers and solutions of fighting with this problem but it was kept silent for a while due to the complexity of the subject. According to 
the diversity and numerosity of these regulations regarding fighting against and criminalization of land use change and illegal occupation as well as the various executive organizations, it can be stated that there is no vivid legal and organizational gap in this regard. But, the question that strikes the mind in this regard is that why this problem is still prevalent in the society even with the enactment of numerous regulations and diverse organizations working for counteracting the land use changes and illegal occupation in Iran? The fact of the matter is that the land speculation phenomenon is the simultaneous output of several factors while the general public most often and mistakenly conjectures that the country's rules and regulations for controlling this problem are flawed and that the problem lies in the legal dimension in the first place. This same lack of exact and comprehensive perception of the land speculation reasons leads to the failure in fighting this problem. The land speculation subject is directly associated with the duties and responsibilities of each of the executive and legislature and judicature branches. It is necessary for these three branches to cooperate and coordinate for fighting with this phenomenon as a trans-sectorial issue [13].

The followings are the most important factors influencing the emergence or corroboration of the land speculation problem:

A) Executive problems: Emergence and expansion of land speculation is more than anything else related to the performance and method of enforcing the land-related rules and regulations within the level of the executive organizations. These organizations include general office of natural resources, land affair administrations, housing and urban engineering, landed property registration, municipalities and other related offices. Thus, lack of coordination between the related and corresponding organs is the most important executive problem.

B) Judicial problems: Lack of the proportion between the crimes and the predicted punishments in the area of land in such a way that they are mostly found incapable of deterrence.

C) Legal problems: Existence of numerous rules and regulations for lands especially the lack of codification of a comprehensive land management law that has led to the confusion and numerosity of the rules and regulations related to the possession of land and owning of land and confusion in the land ownership system in Iran.

D) Economic factors: Stagnation in the country's production sector and numerous problems of the manufacturing institutions directly and indirectly lead to the flowing of capital towards the lands and properties market as a result of which the exorbitant and unreal increase in the prices of the landed properties and growth in the dealership jobs and inclinations towards land use change and illegal land occupation emerge.

In order to counteract such a phenomenon as the forcible and profit-seeking land occupation in the national lands and natural resources and in line with the conservation of the national lands and natural resources and also to support the general laws and prevent the destruction and occupation of the natural resources and lands and also for enforcing the principles 45, 50, 49 and 156 of the constitution, a council was established under the title of "a council for the protection of the public properties' rights in the national lands and natural resources" in 2004 by the order of the then head of judicature. Subsequently, in order to enforce the council's strategies and decisions, a procedure was codified by which the council for the preservation of the public properties' rights was obliged to specifically and particularly refer the investigation of the land crime subjects of land speculation to the corresponding courts with the objective of protecting the rights of the general public and exhibiting decisive reaction to the individuals who commit land occupation, destruction and abuse in the governmental and public properties, agricultural lands, gardens, green spaces, forests and pastures as well as those who perpetrate land use changes for acquiring illegitimate properties and land speculation.

According to articles 3 and 5 of these instructions, the country's attorney general is the secretary of the public treasury rights' protection council and is responsible for forming and administrating the council and pursuing its enactments and supervising the coordination between the institutions in charge; the secretariat of this council is based on the country's attorney general department and it would pursue the assigned tasks. By the force of article 8 of these guidelines, the followings are the duties and authorities of the public treasury rights' protection council in the national lands and natural resources:

1) Identification of the abusers and destructors of the governmental and public properties (mentioned in articles 12 and 13 of the urban land law) and natural resource subjects of the law on the protection and exploitation of the forests and pastures and green spaces and gardens and item subjects of article 1 of the bill on the protection and expansion of green spaces in the cities and the law on the preservation of the uses of the agricultural lands, gardens and tributes (subjects of act 45 of the constitution) and introducing them to the judicial authorities and pursuing the issue to the obtainment of results.

2) Identification of the fabricators of the documents and deeds related to the aforesaid properties and the individuals using them for buying and selling and acquiring profit and introducing the perpetrators to the judicial authorities.

3) Prevention of the fraudulent or unlawful changes of the agricultural lands and gardens' uses 
4) Identification of the abusers to the limits and beds of the lakes, rivers, dams and faults

5) Prevention of renting and wastage of the national, governmental and public lands

6) Identification of the abusers to the unpossessed and non-inherited lands and introducing them to the judicial authorities and performing the required interventions for repelling and counteracting the abuses from the aforementioned lands.

7) Acquiring and collecting information related to national, governmental, public, unpossessed and noninherited lands

8) Performing any required measures for protecting and preventing the occupations and destruction and illegal constructions as well as delimiting and fencing and installing tableau in the aforesaid lands, if necessary [14].

\section{Conclusion}

According to the articles of the law on the nationalization of the country's forests and pastures as the result of government's nationalizing of the lands through its enforcement of its rule of law, the government is to take measures deemed necessary in regard of the public expediencies for safeguarding the public interests. Protection of the natural resources and public wealth and prevention of the destruction of the natural resources is indicative of such a necessity. In between, the collection of the civil reconstruction and development interventions and programs indicate that though emphasis is made in all of the programs on the necessity of protecting the natural resources and revitalization and development of them, the intensity of these resources' destruction has been ascending and increasing and it is yet to be controlled. In fact, numerous factors have been effective in the intensification of the trends of these resources destruction but most important of these problems are the extraneous executive, legal, judicial, social and economic problems. In between, the ambiguity and shortcoming of the existent rules and regulations and weakness in the supports by the judicial authorities of the enforcement of these regulations have exerted far greater effects that should not be left unattended and, though there are various rules and regulations enacted regarding land ownership, conservation of natural resources, support of proprietary rights and prevention of the land use changes and illegal land occupation in Iran's legal system, the counteracting of this problem is faced with numerous executive, legal, judicial, social and economic problems in the country. Moreover, a comprehensive plan of natural resources' lands management should be prepared and enforced based on the land monitoring criteria and scales for preventing the immethodical destruction of the natural resources and dedication and change of the land uses.

\section{References}

[1] Bell, John (2002) 'Property and Legal Culture in France'. Themes in Comparative Law in Honour of Bernard Rudden. Eds. P. Birks and A. Pretto. Oxford: Oxford University Press: 83

[2] Shams, Ahmad, (1996), "investigation of the legal system of nationalized lands”, MA dissertation, law department, Tehran University.

[3] General law research group (2008), "legal system of land ownership in the other countries and its relationship with land speculation", seasonal journal of legal information provisioning, v.6(15\&16).

[4] Karimi, Mahdavi, (2003), "penal support of natural resources in Iran’s laws”, MA dissertation, law department, Islamic Azad University, Tehran-e-Markazi Branch, Tehran, Iran.

[5] Mojtahed Solaymani, Abu Al-Hasan, (2013), "recognition of the national lands from the legal exceptions and objections to it”, MA dissertation, law department, Teacher Training University, Tehran Branch, Tehran, Iran.

[6] Taimuri and Mahdavi, (2016), “investigating the legal status of the nationalized lands and individuals' ownership exceptions and methods of objecting to them”, MA dissertation, law department, faculty of literature and human sciences, Islamic Azad University, Shahroud Branch, Shahroud, Iran.

[7] Jamshidi, Alireza and Amini, Amir Mozaffar, (2012), "evaluating the factors influencing the destruction of pastures from the perspective of the experts of natural resources` office in Ilam Province”, journal of natural resources' protection and exploitation, v.1, (4): 41-67.

[8] Qasemi, N., 2005. Environmental Criminal Law, Jamal al-Haq Publication, Tehran, p236.

[9] Zolghadr, H., 2011. Methods of conditional Prevention of the Crime of defacement of National Territories (Case Study of Fars Province). Master's Degree in Law, Virtual Unit, Shiraz University, Shiraz,p. 10.

[10] Sharifi Sadeh, M., 2015. Investigating the crime of national land grabbing and several questions. Training Message, pp.26: 9-12.

[11] Mashhadi, Ali and Firouzi, Mas’oud, (2003), “a glance at the legal system of land ownership and its relationship with land speculation”, journal of legal information provisioning, issuance nos.15-16, Shahid Beheshti University.

[12] Islamic Consultative Assembly’s Research center, (2004), "natural resources, destruction trends and necessities of regulations' revision”, published by the research center of Islamic Consultative Assembly, Tehran.

[13] Alibeygi, Javad, (2018), “investigating the legal system of rural and nomadic communities' exploitation of the natural resources in Iran”, seasonal journal of human beings and living environment, spring, issuance no.44.

[14] WWW.cppl.ir, database of the council for the preservation of the public treasury and properties' rights in the lands, natural resources and public rights. 